\section{Assisting Reluctant Teacher's College Students to Autonomously Appreciate a Novel to Read}

\author{
Siusana Kweldju \\ Universitas Negeri Malang
}

\begin{abstract}
This paper is a report of how to make reluctant teachers' college students read in a prose course. These students were not interested in fiction and had never read interpretative fiction in English. The teacher sought to know why the students were reluctant to read, and how to make them read, and discovered that it was because of students' linguistic deficiency and their reluctance to read longer texts. The teacher also discovered that in spite of their reluctance they were interested in listening to the teachers' explanation about the cultural elements and the analysis of the short stories. Thus, provided with a guideline developed based on cultural and gender elements, students were motivated to autonomously read an assigned Pulitzer-winning novel.
\end{abstract}

Key words: prose, literature, culture, gender

This paper is a report of the teaching and learning of Prose I at the 6th semester of the English Department of a teachers' college, and how cultural awareness was used as a tool to increase students' interest in reading a novel. It was the first literary course students joined in their 4-year training program to prepare themselves to be teachers of English. The students hardly had any experience with English literature. In general, they were not used to reading full-blown books of fiction both in high school and at the teachers" college. In high schools they were also not required to read fiction in their native language. They read fiction when they were told to, especially in their extensive reading course, and usually they only read es- cape fiction or the abridged versions of the interpretative nature. In average they already read about three novels before taking the prose course. According to them fiction took too much time to read and they preferred reading comprehension passages.

At the first meeting when the teacher asked them whether or not they liked to read fiction, they hesitated to answer the question, but one student was frank enough to say that he did not like to read fiction. When the teacher asked them which writers, short stories and novels they liked best, they were also not quite sure what to respond. However, after joining the class for several meetings they already showed their enthusiasm in understanding fiction and literature. And they realised that literature captured great questions of humanities. Even the student who said that he was not interested in reading fiction showed his enthusiasm.

In the introductory meeting the teacher explained to the students the differences between escape and interpretative fiction. She also showed them several plots of escape fiction, and the students started to show their interest. Then, the teacher continued with what they should read in the semester. Six short stories would be intensively discussed in the classroom and one novel would be autonomously explored by the students.

\section{THE FICTION TO READ IN THE COURSE}

In the limited duration of one semester, it was the short stories, not the novel, which was discussed in the classroom, because six short stories provided more varieties and exposed the students to a wider range of writers, ideas, human problems, styles, subject matters and characters, than one novel. The teacher made it clear to the students that although the short stories were discussed in the classroom, the actual reading was done at home, and they were made to analyse the literary elements of the stories.

The priorities of assigning the students to read a novel autonomously without the teacher's instruction in class included, first, to build the students' ease and confidence in their ability to read. Second, students had the responsibility to individually interpret the novel, so that they did not need to stick to the teacher's opinion. This allowed the students to personalise 
the reading experience toward richness of interpretation and to interpret the story based on their particular belief, personal history, and a set of cultural assumptions. Third, students could independently enter the writer's imagined world, the universality of the themes, the significance of the experiences recounted, and the relevance to their own life, ideas, events and emotions. The fourth priority was to broaden the students' intellectual horizons, sharpen their sensibilities, and see the world in new ways-the qualities essential for every human being.

\section{DEVELOPING STUDENTS' INTEREST IN READING A NEW SHORT STORY}

After joining the course for eight meetings, the teacher realised that students still did not read the fiction as expected at home, because of their limited vocabulary and their limited knowledge of cultural elements. This was obvious when the class started to discuss a new short story. When the teacher checked their comprehension, they seemed to know very little about the story. But after spending a meeting for introductory discussion in class, they began to be motivated to read with more pleasure, instead of finding it a chore.

Basically to read literary texts demands an adequate competence in the language, appropriate cognitive development, accessible references to understand the cultural items in the texts (ICOz, 1992). Therefore, to facilitate comprehension before analysing the literary elements of each story the teacher first of all acquainted the students with the writer's ideas, and sensitised them with the social and cultural elements in the literary text. Understanding the cultural elements of a society-habit, beliefs, customs, and values-enabled them to understand the story from the writer's angle of vision. When the linguistic and cultural deficiency had been overcome, they still needed some guidance to relate one event with another, to analyse the plot, the characterisation, the themes, and so forth. In spite of that, how ever, they enjoyed the course, because when the characterisations and the other elements of the stories were revealed, they could respond to the stories with more imaginations, emotions, and reasoning. Eventually, it could also enhance their awareness in evaluating the qualities of the stories.
There were a lot of means used by the teacher to help students uncterstand the story under discussion. For example, the teacher paired the themes of miniseries on TV with the themes of literary works they read. This is intended to engage the students' social, cultural, and linguistic receptivity to the general points at issue in the text. Students were given specific questions to direct their understanding and analysis.

For example, when they were assigned to read Joseph Conrad's Youth, they said they did not like it, because it was too long, plain, difficult to read, and dull because they were not interested in adventure. However, they totally changed their attitude after the class discussion and after they began to know about:

1. the writer's biography and experience and how the experience was related to Marlow, the narrator in the story,

2. the meaning of the sea to the British, the different idea of being a captain and a skipper of a ship, the meaning of the trial of life, and the irony of the row of accidents Marlow had experienced on the sea, the idea of life and death

3. the characterisation of Marlow, etc.

\section{THE NOVEL READING}

This novel was chosen because it was written by a woman writer, as the short stories read by the students were all written by male writers, and it is also a Pulitzer-prize winning one. The setting took place in a farm in the United States. This is one side of the multifaceted American life. Students might have more knowledge about America as an industrialised country rather than America with its farmlands and the people. This knowledge sharpened the students' awareness to the truth of life that there is no single culture even in America; cultural values always vary. In the novel even sisters' values can differ one from another, and still differ from those of the group to which they belong. Values are not universal even within cultural groups, although there are certain concepts in each cultural group that carry general consensus (Valdes, 1986). 


\section{Through Culture Students Read the Novel}

Although students already knew that reading a novel independently was actually part of their assignment, based on the experience with the short story reading the teacher realised that she could not let them work without any help. Then, the teacher decided to help the students with providing them with a guideline to the assignment. The aim of this help was to increase the students' interest in the story and to motivate them to overcome their language deficiency and their reluctance to read a full-blown book. If they could capture the writer's ideas, with some more help they would be able to read critically. Thus, the teacher's first target was to help the students read with enjoyment, and to enjoy what was worth enjoying. Later, they would emerge as readers with judgement. They would be able to discriminate between the genuine and the spurious, the consequential and the trivial, the significant and the merely entertaining.

According to the teacher's experience students began to be interested in a story when the teacher helped them enjoy the story through comparing the culture or the ways of people in the story with their own. Cultures can be quite similar and quite different, and based on this comparison they might even laugh at their own ways and patterned behaviours, which they were not aware of as they had grown up doing it everyday until they could see that there were other ways of doing it.

The teacher's impression was confirmed by the questionnaire distributed to 60 students that they had more problems with lexical items ( $72 \%$ ) than the cultural ones (58\%), because they already took Cross-cultural Understanding Course. Reading about other people and their behavioural patterns could even deepen their understanding about life, universality, differences, and tolerance. However, since they encountered a lot of unfamiliar vocabulary items they became less interested in reading the stories. But which kind of cultural elements should be utilised? In this case, only significant cultural values, as units, processes and qualities, were counted. Cultures consist of items treated as static units, for example, men, women, parents, children, farms, ideas, and families. Another class is constituted by items treated as processes, for example, to die, to get married, etc. Still another includes items treated as qualities, as for example, hard-workingness, good, bad, faithfulness, love etc
Related to The Thousand Acres students could observe individual independence in a farming community. It has been widely known that the most important American value is independence or individual rights, but in the novel students could specifically learn how independence was among American farmers. Americans might hold individualism much higher than other peoples. In many other countries it is society or family that comes first, not the individual independence in high esteem. Americans also strives to defend their right to maintain it. In fact, once ESL students understand American reverence for individual independence, they are halfway to an understanding of most American literature.

\section{About the Novel: The Thousand Acres}

The Thousand Acres is actually a detailed portrait of Midwestern farm life, how the first settlers started their fortune in the land and how they ventured to drain it with primitive tools among mosquitoes. Later the runoff in the well water they drank poisoned Ginnie (p. 259) and Rose (p. 355). Life was hard work even for a farmer's wife (p. 51). Larry, the second generation added more pieces of land and made himself a millionaire, but he could not keep the third generation to work together in one farm. Farm life had penetrated every part of their life, even the strategies they used in playing the Monopoly games compared to city boys (p. 77). It documented: what the farmers ate, dressed, talked, gossiped and dreamed about, how a farmer loved the farm more than his own wife (p. 342), the temptations they could bear and could not bear anymore in the family, the interference from the people in the neighbourhood and the pastor. The third generation counted the grand history as blows: the hidden incest and the wrath, the hard work in the farm (p. 346), the severe weather (p. 339), illnesses, and death. Then, the third generation preferred to stop the whole business and not to inherit the 640 acres to the fourth generation, and everyone left the farm to town and lived in apartments.

A Thousand Acres was written by a woman writer, and she wrote her story from the standpoint of a woman as represented by the protagonist, who was also a woman with her problems, love, jealousy, happiness, anger, 
hatred, and disappointment. In fact, the writer admits that she rewrote King Lear at a feminist's stance. Women, as mentioned before, are also an item in culture. Students could see how culture had made the protagonist, and other female characters in the novel behaved and how they questioned about it. According to Humm (1986) male authors only wrote about emotions and fears as their cultural fabrication. When a male writer wrote like a feminist, he stili had the possibility to escape-into masculinity and into patriarchy. In fact, both in American and in the students' native culture, women are the second sex, but they saw how the characters reacted to it.

Larry had three daughters, with their own choices. Ginnie was the narrator; Rose was the one who had vengeance against her father, but she was also a jealous and egoistic girl, and Caroline was an independent, smart lawyer, who never wanted to be a farmer's wife, and psychologically was very distant from her two sisters. When she was young she was taken care of and protected by her sisters from their father's abuse. But she never realised and knew it in her life, and was very malignant to her two sisters.

\section{The Ultimate Aim of Reading the Novel}

The aim of reading the novel is for literary appreciation. Students were supposed to answer four literary questions. Since, familiarisation was more emphasised than quality literary reading, there were only four questions to answer, i.e. about complication, conflict and resolution, characterisation, suspense, and irony, as follows:

1. What do you know about the complication and conflict that happened between Ginnie and Ty? (About the miscarriage, about Larry, about Harrold (p. 234), about his personal goal (p.154), about Caroline). What is the climax? How is the resolution? What is the theme we can learn from this novel?

2. Read Chapter 29. Then, read Book 45. What is the irony?

3. Write the characterisation of Rose. Initially she was Ginnie's constant companion (p. 225) and Ginnie adored her (p. 30). Then, write the development about the complication and conflict which led to the climax that Ginnie attempted murder against her
4. What can you talk about the suspense on page 229: "My new life, yet another new life, had begun early in the day."

\section{The Guideline for Reading the Novel}

In order that students could read for character and be sensitive to other elements in fiction, they had to, first of all, comprehend the writer's ideas through the printed text. This guideline consists of comprehension questions and the pages students could refer to for answers, and leads to literary questions. The comprehension questions help students notice important facts, see relationships, avoid misunderstanding, sharpen their sensitiveness to the gender and cultural factors in the novel, awake and hold their interest in reading the novel. Before the guideline was distributed, the teacher had already asked some oral leading questions about the novel at meetings 7,8 and 9 .

Meeting 7

The teacher asked them some questions related to children-parents relationship.

1. Do you love your parents?

2. Everyone is educated to love their parents, but do you always agree with your parents?

3. Do you confront your disagreement with your parents' or do you want to keep the harmony?

4. If you show your disagreement with your parents, will the society approve it?

5. Do you agree that people who are close to you might know the unpleasant relationship that may take place in your family, but they are not close enough to know the particles of the matters, and they might misunderstand the real problem?

Then, the teacher told the students that they were going to understand more about the issue after reading the assigned novel. 


\section{Meeting 8}

The novel is given to students at the eighth meeting of the semester, and the teacher gave some comments about the novel:

1. The novel is a Pulitzer-prize winning one and a best seller.

2. It is a novel about families and their troubles, cares, and tensions, which took place on the American Middle Western farmland. It also recorded the hardships of the farmers, in spite of the rich and lush farms.

\section{Meeting 9}

The teacher asked the students whether they had read the novel and whether they began to be interested in it. The teacher told them about the writer.

Jane Smiley was born on September 26, 1949 in Los Angeles, CA. She got married four times and divorced three times. She obtained her Ph.D in 1978 and is presently a professor of English at Iowa State University, Ames. She has already written eight novels, and a number of stories and novellas.

A Thousand Acres is a subtle account of a family's disintegration. It is a deliberate recasting of King Lear and the three daughters, who plotted to take control of his kingdom. In the novel Ginny, the first daughter, showed the deleterious impact of her father Larry's decision to divide his multimillion dollar farm among his three daughters, which includes the embittered Rose and the emotionally distant Caroline. As the divided enterprise deteriorates, marriages fall apart and family relationships are crippled by suspicion and betrayal. In this story we can see the portrait of American farm and the community, patriarchal culture and incest, and how to painfully overcome it.

\section{Meeting 10}

After the teacher thought that students had enough time to independently read the novel the teacher gave out the written guideline. Reading independently was to create a situation in which students could guess and speculate, to see previous relations and the direction where the logic could lead. This guideline is made culturally-and gender-based. In the guideline the teacher did not tell the students the plot or the theme of the stories.

The questions to answer were developed based on American cultural values and gender issues:

1. Individuality in many ways

2. The American dream

3. Early settlers and farmers

4. Materialism

5. Education

6. Being a farmer, his dream, skill, struggle, his envy, his equipment, extended family, and the weather

7. Banking and taxes

8. Marriage, nuclear family and extended family

9. Husband-wife relationship, faithfulness and the termination of the relationship

10. Ambitious parents

11. Men's and women's roles, jobs and suffering

12. A woman's dream and jealousy

13. Many types of women: with one and multiple choices, and farmers' wives

14. Good manners

15. Wife beating

16. Children's love and hatred to their parents; approval and disapproved by the society

17. Good children

18. Virginity, rape, incest

19. Being drunk

20. A father's figure, and a cursing father

21. Being retired

22. City and farm boys

23. Women's health problem 
This following is an example of a topic in the guideline under the issues of individuality, virginity, rape and incest:

\section{Individuality}

In any culture, including in American culture, where individuality and independent conscience are deeply respected, a young person will obey the dictates of society and follow its customs. People are supposed to have good manners (pp.12, 46). There is a balance between conformity and individuality. Can children be angry to their parents? (pp. 54, 55, 56, 159, 182 , $185,188-92,196,235,247,278,280,302)$. Did Ginny and Rose violate this value system according to you? Was there any motivation which made them behave that way? Is it true that they deliberately reject the values? How about Caroline? How about Jesse to Harold? Was it fair enough for the people to disapprove of them and thought that they were selfish? Why did Ginny think, "All these neighbors close enough to know our business, but too infinitely far from us to feel a particle of what we were feeling, themselves feeling animated, more than anything, by the pleasures of curiosity" (p. 347)? Could you see that American society differentiate between individuality and negligence to obligation? Even in American society conformity or individuality are supposed to be in a balance (pp. 203-4, 214-15, 247).

Americans have confidence in individualism. Marriage is considered more a private than a public decision. Did Caroline ask her father's consent for her manriage? Was it possible in Indonesia, how angry you are to your parents, that you do not ask your father's consent for the marriage? Is it possible that a girl is married to a boy without any marriage proposal to the girl's parents? When can a child be more independent (p.60)?

\section{Virginity, Rape and Incest}

Who was raped in the story? When a woman was raped or when there was an incest in the family, was it easy for a woman to tell it to anyone for justice? Even if she did so, could people approve it? According to you, are there a lot more rapes and incests in your own society than what was disclosed in the newspaper? Was it easy for Rose to talk about it to Ginnie? Could Ginnie remember the rape actually? Why didn't she want to say about it? Was it true that women's virginity was more important than men's in the novel? What do you think with the value in your own society? (pp. $188,189-92,228-9,247,278-80,340$ ).

\section{Meeting 16}

Meeting 16 was the deadline for students to submit their assignment It was discovered that students could answer the comprehension questions, but they were still unable to answer the literary questions. Answering the comprehension questions students could directly refer to the suggested pages to read. Their job was simply to restate what they could immediately discover in the novel. However, to answer the literary questions they should improve and polish their intellectual, sensuous and emotional apprehension. They should employ their explanatory and interpretative power after studying the qualities of the novel, like the logical sequences and the relations of events, the description of the characters, the analysis of the elements and symbols utilised in the novel.

\section{CONCLUSION}

Studying prose in one semester only was not sufficient to help English Department students to fully understand and appreciate literature. Prose One was only successful to expose the students to the experience of reading interpretative fiction and to change their attitude from reluctant and indifferent fiction readers to interested ones. 
Basically they still had a problem to read interpretative short stories and novels, especially because of their limited vocabulary and their limited experience in reading longer discourse, because they were more accustomed to reading comprehension passages. Therefore, before a story was explained and analysed by the teacher they inclined to say that the story was too long, difficult, and dull. However, after the teachers' explanation they were fascinated by the stories.

In short, taking Prose I students could only maximise themselves with six short stories and one novel. With the exercise of analysing six short stories and the rigorous guidance of independently reading a novel, students could only read a novel for comprehension but not for literary analysis and interpretation. This paper also recommends that Prose II is an obligatory rather than an optional course. In fact, fiction can help students improve their English. Tolerance to different cultures and habits can be cultivated from literature.

\section{REFERENCES}

Humm, M. 1986. Feminist Criticism: Women as Contemporary Critics. Hertfordshire: Simon and Schuster International Group.

Icoz, N. 1992. Teaching Literature. English Teaching Forum. 30(1).

Smiley, J. 1991. A Thousand Acres. New York: Fawcett Columbine.

Valdes, J.M., 1986. Culture in Literature. In J.M. Valdes, Culture Bound: Bridging the Cultural Gap in Language Teaching. Cambridge: Cambridge University Press. 